\title{
The Results of the General Traffic Measurements Analysis on the Example of Łódź Voivodeship (in Poland)
}

\author{
Elżbieta Macioszek ${ }^{*}$, Grzegorz Sierpiński, Marcin Staniek and Damian Lach \\ Transport Systems and Traffic Engineering Department, Faculty of Transport, Silesian University of Technology, Poland \\ *Corresponding author
}

\begin{abstract}
The article presents the results of a detailed analysis of data from the General Traffic Measurements carried out in the years 2000 - 2015 on voivodeship roads. The analysis was carried out on the results from the Lódź Voivodeship in Poland.
\end{abstract}

\section{Keywords-traffic engineering; road traffic measurements}

\section{INTRODUCTION}

es in AADT values in the years 2000c measurements and surveys are the basic source of data for conducting further various types of analyzes (f.ex. [1-8]). The article presents the results of a detailed analysis of data from the General Traffic Measurements (GTM) carried out in the years 2000 - 2015 on voivodeship roads. The analysis was carried out on the results from the Łódź Voivodeship in Poland. The analysis included such features as:

- $\quad$ annual average daily traffic (AADT) in voivodeship;

- annual avarage daily traffic divided into particular generic groups, such as: motorcycles, passenger cars, light trucks, lorries without trailers, lorries with trailers, buses and agricultural tractors; traffic;

Load of voivodeship roads with annual avarage daily

- Load of voivodeship roads with annual avarage daily traffic divided into particular generic groups.

In addition, AADT changes were analyzed on the three most-intensive voivodship roads.

\section{CHARACTERISTICS OF THE VOIVODESHIP ROADS NETWORK IN THE ŁÓDŹ VOIVODSHIP (IN POLAND)}

The Łódź Voivodeship is located in the central part of the country. Its capital and main administrative center is Łódź. According to data published by the Central Statistical Office (GUS), in 2017 [9], about 2.5 million inhabitants live in the aforementioned region, which with not the largest area (18200 $\mathrm{km}^{2}$ ) gives a population density of about 137 people $/ \mathrm{km}^{2}$ (fifth result in the country). The Lódź Voivodeship has a very extensive network of roads, in particular when it comes to national roads. The A1 and A2 motorways as well as the S8 and $\mathrm{S} 14$ expressways pass through its areas. In addition, this area is characterized by a dense network of provincial roads, whose total length is $1152.4 \mathrm{~km}$, of which $125.4 \mathrm{~km}$ are located in urban areas. The list of roads in the Łódź Voivodeship is shown in Table 1.

TABLE I. THE LIST OF ROADS IN ŁÓDŹ VOIVODESHIP (IN POLAND). SOURCE: OWN RESEARCH ON THE BASIS OF [10-13]

\begin{tabular}{|c|c|}
\hline $\begin{array}{l}\text { Number } \\
\text { of road }\end{array}$ & The route of the road \\
\hline 449 & Syców - Ostrzeszów - Błaszki \\
\hline 450 & Kalisz - Grabów nad Prosną -Wyszanów -Wieruszów -Opatów \\
\hline 469 & Uniejów - Gostków - Wróblew \\
\hline 473 & Koło - Dąbie - Uniejów - Balin - Szadek - Łask \\
\hline 478 & Rzymsko - Księża Wólka - Krępa \\
\hline 479 & Dąbrówka - Sieradz \\
\hline 480 & Lask - Widawa - Szczerców \\
\hline 481 & Łask - Widawa - Widoradz Górny \\
\hline 483 & Łask - Szczerców - Nowa Brzeźnica - Częstochowa \\
\hline 484 & Buczek - Zelów - Bełchatów - Kamieńsk \\
\hline 485 & Pabianice - Wadlew - Bełchatów \\
\hline 486 & Wieluń - Droga 43 - Działoszyn \\
\hline 491 & Działoszyn - Droga 42 - Łobodno - Częstochowa \\
\hline 492 & $\begin{array}{l}\text { Ważne Młyny - Łobodno - Kołbuck - Wręczyca Wielka - } \\
\text { Błachownia }\end{array}$ \\
\hline 573 & Nowy Duninów - Gostynin - Żychlin \\
\hline 581 & Gostynin - Łanięta - Krośniewice \\
\hline 583 & Bedlno - Żychlin - Sanniki \\
\hline 584 & Sanniki - Kiernozia - Łowicz \\
\hline 702 & Kutno - Piątek - Zgierz \\
\hline 703 & Porczyny - Poddębice - Gostków - Łęczyca - Piątek - Łowicz \\
\hline 704 & Jamno - Kołacin - Brzeziny \\
\hline 705 & Śladów - Sochaczew - Skierniewice - Jeżów \\
\hline 707 & Skierniewice - Rawa Mazowiecka - Nowe Miasto nad Pilicą \\
\hline 708 & Ozorków - Warszyce - Stryków - Brzeziny \\
\hline 710 & Łódź - Konstantynów Ł. - Szadek - Warta - Błaszki \\
\hline 713 & $\begin{array}{l}\text { Łódź - Andrespol - Kurowice - Ujazd - Tomaszów } \\
\text { Mazowiecki - Januszewice }\end{array}$ \\
\hline 714 & Rzgów - Kurowice \\
\hline 715 & Brzeziny - Koluszki - Budziszewice - Ujazd \\
\hline 716 & Koluszki - Rokiciny - Piotrków Trybunalski \\
\hline 725 & Rawa Mazowiecka - Biała Rawska - Bielsk Duży \\
\hline 726 & Rawa Mazowiecka - Inowłódz - Opoczno - Żarnów \\
\hline 728 & Grójec - Nowe Miasto Nad Pilicą - Końskie - Łopuszyno \\
\hline 742 & Przygłów - Łęczno - Ręczno - Włoszczowa - Nagłowice \\
\hline 746 & Żarnów - Końskie \\
\hline 784 & Radomsko - Ciężkowice - Święta Anna \\
\hline 785 & Ciężkowice - Żytno - Maluszyn - Włoszczowa \\
\hline
\end{tabular}




\section{ANALYSIS OF THE RESUlTS OF GENERAL TRAFFIC MEASUREMENTS IN THE YEARS 2000-2015 IN THE ŁÓDŹ VOIVODSHIP (IN POLAND)}

The AADT is the basic parameter calculated for all road sections of provincial road network and the method of its calculation depends on type of measuring point. For basic road sections and for road sections passing through towns where traffic measurements are performed on full-time the AADT value is calculated from equation [14]:

$$
A A D T=\frac{A_{1} \cdot N_{1}+0,85 \cdot A_{2} \cdot N_{2}+A_{3} \cdot N_{3}}{N}+A N\left(\frac{\text { veh }}{24 \text { hours }}\right)
$$

Where:

AADT- annual average daily traffic,

$\mathrm{A}_{1}$ - average daily traffic on weekdays from Monday to Friday, from $6.00 \mathrm{pm}$. to $22: 00 \mathrm{am}$,

$0.85 \cdot \mathrm{A}_{2}$ - average daily traffic on Saturdays and pre-holiday days, from $6.00 \mathrm{pm}$. to $22: 00 \mathrm{am}$,

$\mathrm{A}_{3}$ - average daily traffic on Sundays and holidays, from $6.00 \mathrm{pm}$. to $22: 00 \mathrm{am}$,

ANT- average night traffic, from 22:00 am. to 6:00 pm,

$\mathrm{N}_{1}$ - number of working days in a year,

$\mathrm{N}_{2}$ - number of Saturdays and pre-holiday days in the year,

$\mathrm{N}_{3}$ - number of Sundays and holiday days in a year,

$\mathrm{N}$ - number of all days in the year.

On the Fig. 1a shows changes in the value of the annual average daily traffic on provincial roads in the Łódź Voivodeship in the years 2000-2015. On the basis of Fig. 1a, an increase in the AADT value in the discussed region can be seen. This increase, similarly to the entire country, can be described as almost systematic. In 2015, there was a very small increase in AADT in comparison to the previous measurement made in 2010. The largest change in AADT was recorded in 2010, when the rate was 4056 vehicles/day, which gives an increase of $25 \%$ compared to the previous measurement made in 2005.

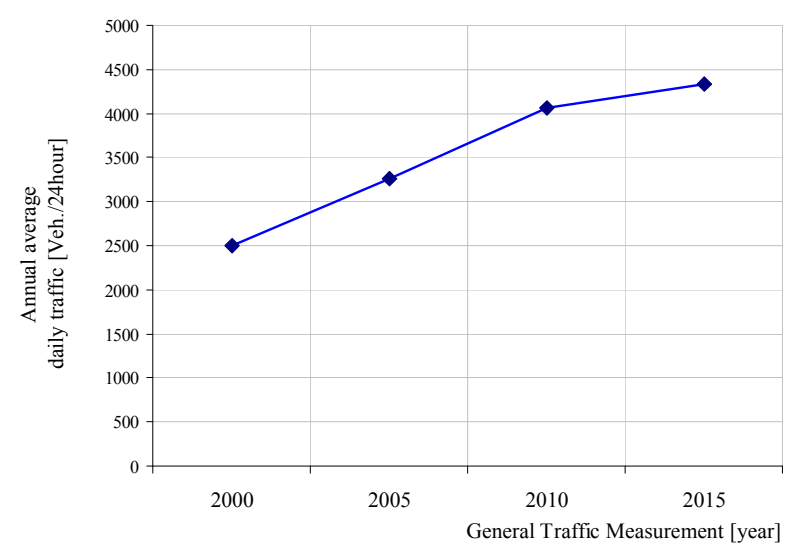

(a)

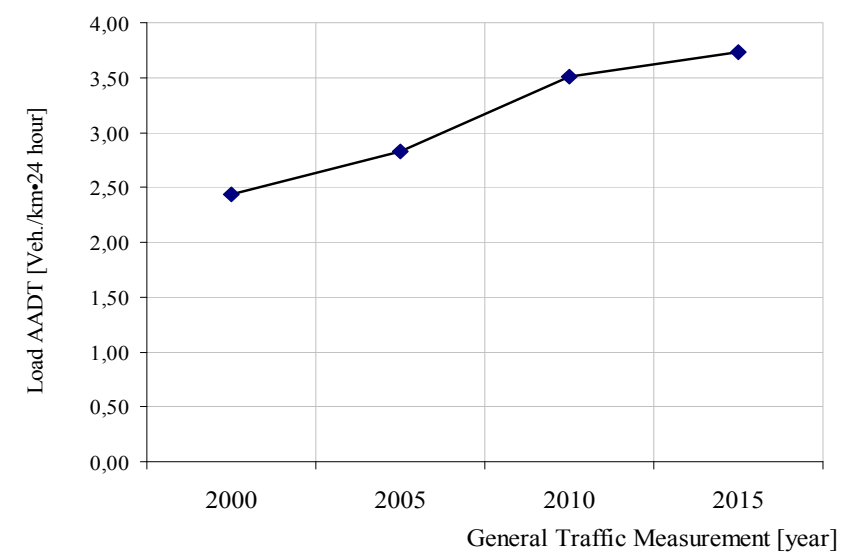

(b)

FIGURE I. A) CHANGES IN THE AADT VALUE ON VOIVODESHIP ROADS B) THE LOAD OF AADT ON VOIVODESHIP ROADS IN THE ŁÓDŹ VOIVODESHIP IN THE YEARS 2000-2015

In turn, Fig. 2a presents changes in the AADT value divided into particular generic groups of vehicles. On the basis of Fig. $2 \mathrm{a}$, it can be stated that passenger cars traffic in 2000-2010 on voivodeship roads in the region undergoes a systematic increase. In 2015, the increase in AADT was lower than in previous years and amounted to $8 \%$. In the years 2000-2015, the value of AADT of passenger cars increased by $82 \%$ in total.

The largest increase in AADT value of motorcycles was recorded in GTM 2010. In relation to the previous measurement, this index increased by 27 vehicles/day, i.e. by as much as $225 \%$. In the years $2000-2005$, there was a slight decrease in the value of AADT (by 8\%). However, in GTM 2015 , a small increase in the value of this indicator was found in relation to the measurement made in 2010 by $3 \%$.

The intensity of light truck traffic on voivodeship roads in the years 2000-2010 has been systematically increasing. This trend has changed in GTM 2015, in which there was a drop in the AADT value of light goods vehicles. In relation to the measurement made in 2010 , the value of AADT decreased by $12 \%$.

The largest increase in the value of AADT for trucks without trailers was recorded in 2010. In comparison to the previous measurement, this indicator has changed by 47 vehicles/day (i.e. an increase of 37\%). The GTM 2005 also recorded an increase in the AADT value in relation to the previous measurement, however, it was not as significant as in the above-mentioned GTM 2010 and amounted to only $8 \%$. The upward trend has changed in 2015, when the AADT value of lorries without trailers has decreased by $15 \%$ compared to the previous measurement.

AADT values of trucks with trailers in the years 2000-2015 were growing. This increase can be described as irregular. The highest increase in the value of this indicator was recorded in 2010, when the movement of trucks with trailers changed by 102 vehicles/day (i.e. an increase of $70 \%$ ). In the remaining measurements, the increase was $41 \%$ in 2005 and $11 \%$ in 2015 , respectively. 
Changes in the AADT value of buses in the years 2000-2015 were very irregular. In 2005, the discussed indicator increased by $19 \%$. In all subsequent measurements this movement was in a downward trend. However, in 2010, the drop in the bus AADT was very small and amounted to $2 \%$. In the GTM 2015, a 24\% reduction in the value of the discussed indicator was recorded compared to the GTM 2010.

In the years 2000-2005 and 2010-2015, there was a decrease in the value of AADT of agricultural tractors. Changes in the value of this indicator were similar in both periods and amounted to $27 \%$ in 2005 and $29 \%$ in 2015 , respectively. In GTM 2010 there was a minimal increase in the AADT value of agricultural tractors in relation to the previous measurement. The increase was $6 \%$.

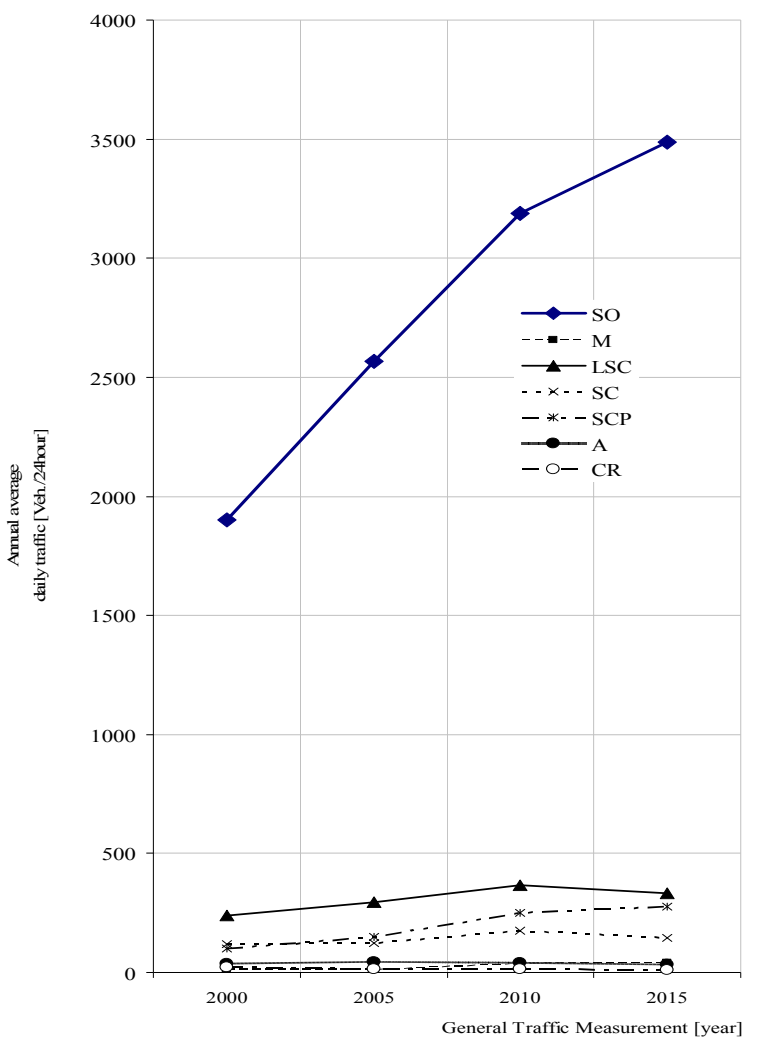

a)

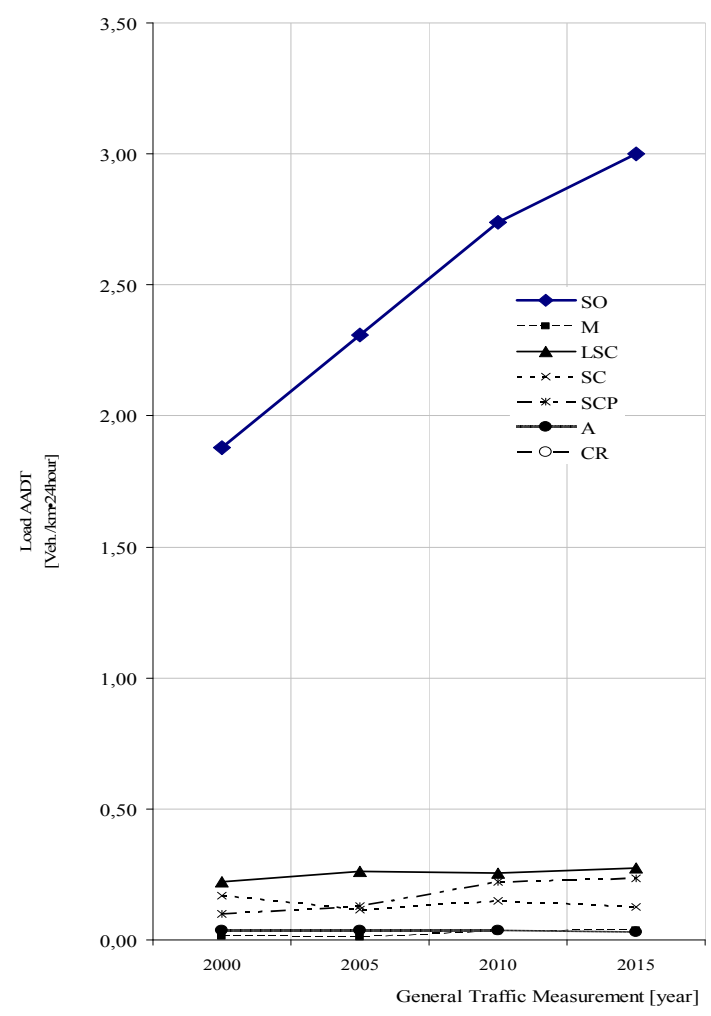

b)

(Where: SO - passenger cars and vans, M - motocycles, LSC - light trucks, SC lorries, SCP - lorries with trailers, A - buses, CR - agricultural tractors)

FIGURE II. A) CHANGES IN THE AADT VALUE DIVIDED INTO INDIVIDUAL GENERIC GROUPS, B) CHANGES IN THE LOAD OF

THE VOIVODSHIP ROADS NETWORK OF THE ŁÓDŹ VOIVODESHIP AADT DIVIDED INTO INDIVIDUAL GENERIC GROUPS IN THE YEARS 2000-2015

On the Fig. 1b shows changes in the load of the voivodeship road network in the Łódź Voivodeship AADT in the years 2000-2015. On the basis of Fig. 1b, it can be stated that the load of voivodeship roads over the entire AADT analysis period has increased. The highest value of AADT was recorded in GTM 2015 and it amounted to 3.69 vehicles $/ \mathrm{km} \cdot$ day. The lowest value of the AADT road load was obtained in GTM 2000 and it amounted to 2.38 vehicles $/ \mathrm{km} \cdot d a y$. In the years $2000-2015$, the value of this indicator increased by a total of $55 \%$.

On the Fig. 2b shows changes in the load of voivodeship roads in the Łódź Voivodeship AADT divided into individual generic groups in the years 2000-2015. The load values of AADT road network increased. The minimum value was recorded in GTM 2000 and it amounted to 1.81 vehicles $/ \mathrm{km} \cdot$ day. The maximum value was obtained in the study, which was carried out in 2015 and it amounted to 2.96 vehicles $/ \mathrm{km} \cdot$ day. Throughout the analysis period, the value of the load on the road network AADT of passenger cars increased by $64 \%$.

As can be seen on Fig. 2b, at the beginning of the analyzed period, i.e. in GTM 2005, there was a minimal decrease in the road load AADT of motorcycles by about $12 \%$ in relation to the measurement made in 2010. The largest escalation of the 
discussed indicator took place in the GTM 2010. There was a very large increase in road load of AADT motorcycles $(0,035$ vehicles/km·day). In the years 2000-2015, the load on the AADT of motorcycles increased by as much as $216 \%$.

In the case of a generic group of light trucks, it can be stated that in the years 2000-2015 the increase in the value of the AADT road network load was dominating. Only in the GTM 2010 there was a slight decrease in this indicator (by almost $1 \%$ ). The minimum value of the load on AADT road network for light trucks was obtained in GTM 2000, which was then 0,221 vehicles $/ \mathrm{km} \cdot$ day. The maximum value was recorded in GTM 2015 and amounted to 0,281 vehicles $/ \mathrm{km} \cdot$ day. Throughout the analysis period, the load value of AADT road network for light trucks increased by $27 \%$.

Changes in the load on the AADT road network for lorries without trailers were irregular. At the beginning of the analyzed period, i.e. in the GTM 2005, there was a slight decrease in the value of the said ratio in relation to GTM 2000 by $2 \%$. Also in this study, a minimum value was obtained in the entire analyzed period, which was 0,110 vehicles $/ \mathrm{km}$ ·day. The largest increase in the road load of AADT trucks without trailers was recorded in GTM 2010 (increase by 37\%). In this study, the maximum value of the indicator was also obtained, which was 0,150 vehicles/km·day.

The value of the load on the AADT road network for lorries with trailers increased throughout the analyzed period. The largest increase - by as much as 70\% - was recorded in the GTM 2010. The maximum value of this indicator was recorded in GTM 2015 and amounted to 0,239 vehicles $/ \mathrm{km} \cdot$ day. However, the minimum value was recorded in 2000 and it amounted to 0,100 vehicles $/ \mathrm{km} \cdot$ day. Throughout the analysis period, the load on the AADT road network for lorries with trailers increased by almost $140 \%$.

In turn, the load values of the bus AADT road network did not change significantly. It was not until the GTM 2015 that a clear decrease of this indicator by $24 \%$ was noted. In the same study, the minimum value of bus load AADT for buses was obtained, which was 0,029 vehicles $/ \mathrm{km} \cdot$ day.

In the years 2000-2015, the decrease of the load value of AADT road network of farm tractors was dominating. Only in the GTM 2010 there was a slight increase of the mentioned indicator by $7 \%$. Throughout the analysis period, the load on the AADT road network of agricultural tractors decreased by $51 \%$.

In the next stage of the work, voivodeship roads with the largest AADT in the Łódź Voivodeship in 2015 were analyzed in detail. These are roads DW 485, DW 713 and DW 714. On the Fig. 3 shows changes in AADT values in the years 2000-2015 on these three roads. On the basis on Fig. 3 can be stated that AADT values on voivodeship road No. 485 increased in each subsequent GTM. In 2015, the result was 7969 vehicles/day. It was the largest AADT value among all surveyed voivodeship roads. In GTM 2000, the obtained value of this indicator was also the highest in the voivodeship. On the other hand, in the subsequent measurements, the received SDRR values were respectively the second in 2005 and the third in 2010, the result of the largest of all voivodeship roads in the discussed region. In the years 2000-2015, the AADT value on the voivodeship road No. 485 increased by $51 \%$.

On the other hand, the AADT value on voivodeship road No. 713 increased in 2000-2005 and in 2010-2015. In GTM 2010 there was a minimal decrease in this indicator. In the research carried out in 2015, the value of AADT was 7,859 vehicles/day. It was the second largest result among all voivodeship roads in the discussed region. In previous measurements, the values recorded were respectively the second in 2000, the first in 2005 and the fifth in 2010 as the largest result among all voivodeship roads in the discussed region. Throughout the analysis period, the value of AADT on the voivodeship road No. 713 increased by $59 \%$.

The values of AADT on provincial road No. 714 increased in each subsequent measurement. In GTM 2015, the AADT value was 7,542 vehicles/day. It was the third largest result among all voivodeship roads in the discussed region. In previous measurements, the values recorded were respectively the fourth in 2000 and 2010 and the third in 2005 as the largest result among all voivodeship roads in the discussed region. Throughout the analysis period, the value of AADT on the voivodeship road No. 714 increased by $81 \%$.

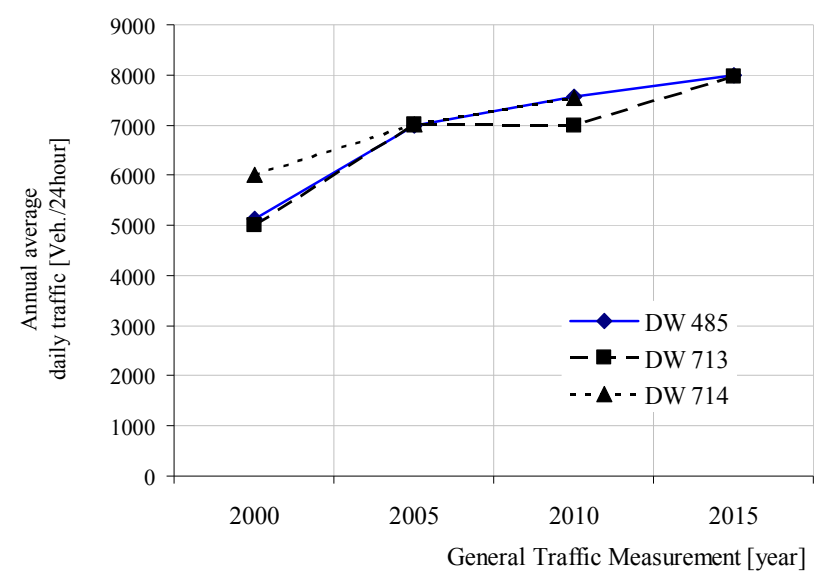

FIGURE III. CHANGES IN THE VALUE OF AADT OF DW 485, DW 713 AND DW 714 IN THE YEARS 2005-2015 IN THE ŁÓDŹ VOIVODESHIP

\section{SUMMARY}

Based on results of the analyses addressing the general traffic measurements in Łódź Voivodeship over the years 2000 - 2015 one could formulate the following conclusions:

- Passenger car traffic on voivodeship roads has been systematically growing. In 2015 , the increase in the value of AADT was lower than in previous years and amounted to $8 \%$. Throughout the analysis, the value of AADT for passenger cars increased by $82 \%$,

The highest increase in AADT value of motorcycles on voivodeship roads was recorded in GTM 2010. In comparison to the previous measurement, this index increased by 27 vehicles/day (i.e. an increase of $225 \%$ ). Throughout the 
analysis period, the AADT value of motorcycles increased by $222 \%$,

- The light trucks traffic has been systematically increasing. This trend has changed in GTM 2015, in which the decline in the AADT value of light goods vehicles was recorded for the first time in the discussed period. In relation to the measurement made in 2010, the value of AADT decreased by $12 \%$,

- $\quad$ The largest increase in the value of AADT for trucks without trailers was recorded in 2010. In comparison to the previous measurement, this indicator has changed by 47 vehicles/day (i.e. an increase of $37 \%$ ). The upward trend changed in 2015, when the value of AADT of trucks without trailers compared to the previous measurement decreased by $15 \%$,

AADT values for trucks with trailers have increased. This increase can be described as irregular. The largest increase in the value of this indicator was recorded in 2010. The increase was then $70 \%$,

Changes in bus AADT values were very irregular. In 2005 , the discussed indicator increased by $19 \%$ in relation to the results from the previous measurement. In subsequent measurements, this movement was declining, while in 2010 the drop in the value of AADT for buses was very small and amounted to less than 2\%. In GTM 2015, a larger reduction in the value of the indicator was noted (by about 24\%),

- During the entire analysis period, the AADT values of agricultural tractors dropped. The decreases in the value of the indicator in question were respectively $27 \%$ in 2005 and $29 \%$ in 2015. The exception is the GTM 2010, in which there was a minimal increase in the value of AADT of agricultural tractors (by $6 \%$ ) in relation to the previous measurement,

- In the entire analysis period, the value of the voivodeship roads load of AADT increased by almost 55\%;

- For voivodeship roads where the highest AADT values were recorded in 2015 include roads: DW 485, DW 713 and DW 714,

- In the years 2000-2015, the AADT values on each of these three roads increased by $51 \%$ respectively to DW 485 , by $59 \%$ at DW 713 and by as much as $81 \%$ at DW 714 .

\section{ACKNOWLEDGEMENT}

This research was supported by the Transport Systems and Traffic Engineering Department, Faculty of Transport, Silesian University of Technology.

\section{REFERENCES}

[1] T. Szczuraszek, E. Macioszek, Proportion of vehicles moving freely depending on traffic volume and proportion of trucks and buses, The Baltic Journal of Road and Bridge Engineering 8, no 2 (2013) 133-141.

[2] E. Macioszek, Relationship between vehicle stream in the circular roadway of a one-lane roundabout and traffic volume on the roundabout at peak hour, in: J. Mikulski (Ed.), Telematics - Support for Transport. CCIS, Springer, Heidelberg 2014, vol. 471, pp. 110-119.
[3] E. Macioszek, The influence of motorcycling and cycling on small one-lane roundabouts capacity, in: J. Mikulski (Ed.), Modern Transport Telematics. CCIS, Springer, Heidelberg 2011, vol. 239, pp. 291-298.

[4] E. Macioszek, D. Lach, Analysis of the results of general traffic measurements in West Pomeranian Voivodeship over the years 2005-2015, Scientific Journal of Silesian University of Technology. Series Transport. 97 (2017) 95-104 (in press).

[5] E. Macioszek, M., Czerniakowski, Road traffic safety-related changes introduced on T. Kościuszki and Królowej Jadwigi Streets in Dabrowa Górnicza between 2006 and 2015. Scientific Journal of Silesian University of Technology. Series Transport. 96 (2017) 95-104.

[6] E. Macioszek, Geometrical determinants of car equivalents for heavy vehicles crossing circular intersections, in: J. Mikulski (Ed.), Telematics in the Transport Environment. CCIS, Springer, Heidelberg 2012, vol. 329 , pp. 221-228.

[7] [7] E. Macioszek, Analysis of significance of differences between psychotechnical parameters for drivers at the entries to one-lane and turbo roundabouts in Poland, in: G. Sierpiński (Ed.), Intelligent Transport Systems and Travel Behaviour. AISC, Springer, Switzerland 2017, vol. 505, pp. 149-161.

[8] E. Macioszek, Analysis of the effect of congestion in the lanes at the inlet to the two-lane roundabout on traffic capacity of the inlet, in: J. Mikulski (Ed.), Activities of Transport Telematics. CCIS, Springer, Heidelberg 2013, vol. 395, pp. 97-104.

[9] Central Statistical Office. Area and population in territorial cross section in 2017, http://stat.gov.pl/

[10] General Director of National Roads and Motorways. Order No 74 of the General Director of National Roads and Motorways of 2 December 2008 on Numbering Voivodship Roads, https://www.gddkia.gov.pl/userfiles/articles/z/zarzadzenia-generalnego-d yrektor_6335//documents/32_2004.pdf

[11] General Director of National Roads and Motorways. Order No 78 of the General Director of National Roads and Motorways of 11 December 2009 Amending the Ordinance on the Numbering of Voivodeship Roads, https://www.gddkia.gov.pl/userfiles/articles/z/zarzadzenia-generalnego-d yrek tor_3184//documents/ scan2080.pdf

[12] General Director of National Roads and Motorways. Order No. 45 of the General Director of National Roads and Motorways of 17 December 2012 Amending the Ordinance on the Numbering of Voivodeship Roads, https://www.gddkia.gov.pl/userfiles/articles/z/zarzadzenia-generalnego-d yrek tor_10385/zarzadze nie\%2045.pdf

[13] General Director of National Roads and Motorways. Order No 61 of the General Director of National Roads and Motorways of 20 December 2013 Amending the Ordinance on the Numbering of Voivodeship Roads, https://www.gddkia.gov.pl/userfiles/articles/z/zarzadzenia-generalnego-d yrek tor_11943/zarzadze nie\%2061.pdf

[14] General Traffic Measurements Guidelines on Provincial Roads in 2015, https://www.gddkia.gov.pl/userfiles/articles/g/generalny-pomiar-ruchu-w -2015_15598/Wytyczne\%20GPR\%20na\%20dr\%20woj\%20w\%202015 $\% 20$ r_zakceptowane_ok.pdf 